\title{
Comparison of indoor air pollutants concentration in two Romanian classrooms
}

\author{
Vasilica Vasile $^{1}$, Alina Dima ${ }^{1}$,Elena Zorila ${ }^{2,3}$, Andrei Istrate $^{2,3}$, Tiberiu Catalina ${ }^{2,3}$ \\ ${ }^{1}$ INCD URBAN-INCERC Bucharest, Laboratory PFCH Pantelimon, 266, Bucharest, Romania \\ ${ }^{2}$ Technical University of Civil Engineering Bucharest Blvd. Pache Protopopescu 66, Bucharest, Romania \\ ${ }^{3}$ Babes-Bolyai University, Faculty of Environmental Science and Engineering 30, Fântânele Street, Cluj Napoca
}

\begin{abstract}
This paper investigates the air pollutions in space ventilated in two High School classrooms. The analysis consists of comparison of one classroom with hybrid ventilation system and another one stander-by classroom with natural ventilation. Several studies regarding indoor air quality during the experimental campaign have been done for $\mathrm{VOC}, \mathrm{CO}_{2}, \mathrm{CO}$, other pollutants, keeping monitored for humidity and temperature. The experimental demonstrated that the highest value for $\mathrm{CO}_{2}$ in stander-by classroom is 2691 ppm and in classroom with hybrid ventilation is $1897 \mathrm{ppm}$, while values for CO are 1.1/1.1 ppm and VOC 0.14 / $0.06 \mathrm{ppm}$, better use hybrid ventilation.
\end{abstract}

\section{Introduction}

Air quality of indoor environments draw considerable attention from the public as well as from the researchers [1] because relatively higher pollutant concentrations in combination with longer time spent indoors can result in higher exposures and can produce adverse health effects (Ugranli et al., 2015, Zhong et al., 2017) [2, 3]. All over the world [3], indoor monitoring of air compounds is an ongoing challenge (Ho et al., 2016) [4], numerous studies being in progress, whether it is office or dwelling buildings or schools $[3,5-9,10]$.

Educational institutions are one of the most studied indoor environments with a focus on kindergartens and primary or high schools, because of the high density population potentially vulnerable who are still growing, making them especially susceptible to the effects of pollution (Ugranli et al., 2015, Zhong et al., 2017) [2, 3]. Our previous studies relating the monitoring of indoor air from different type of spaces showed high values of the carbon dioxide concentrations in the most of cases. For example, the average values of carbon dioxide concentration monitored during three experimental campaigns in residential spaces, first in March-May 2014, ranged between $898 \mathrm{ppm}$ and $1,306 \mathrm{ppm}$, the second in September-October 2014, with average values between $811 \mathrm{ppm}$ and 3,111 ppm and the third in MarchApril 2015, with values between 1,128 ppm and 2,490 ppm (Vasile et al., 2016) [5-9]. It appears that in all three monitored residential spaces there are high concentrations of carbon dioxide, which exceeded up to three times the limit allowed in indoor air. These high values of the concentrations of carbon dioxide in the space of a kitchen are justified since the cooking activities results in generation of carbon dioxide by combustion. It is interesting to note that, the same high concentrations are found in the bedrooms leading to the conclusion that these spaces are deficient in terms of ventilation and of the assurance of necessary fresh air. Also, the average concentration values of carbon dioxide, monitored in office spaces during March-April 2012 (National Project PN 091404 02, 2012) [11] were between $661 \mathrm{ppm}$ and 1,018 ppm, those recorded in the period of February-March 2015, ranged between 888 and 1,668 ppm (Vasile et al., 2017) [12], and those monitored in November 2015, inside the spaces for the educational process in higher education (chemistry lab), were between 912 ppm and 990 ppm (Vasile et al., 2016) [5-9], over the permissible limit of 800 ppm [10].

Average concentrations of carbon dioxide between 1,720 ppm and 4,302 ppm (National Project PN 09140402 , 2015) $[13,14]$, two to five times the tolerable limit of $800 \mathrm{ppm}$, as determined by OSHA [10], were recorded in the investigated educational sites (kindergartens, secondary and high schools) during September-October 2015 , and when talking about spaces where children are working, ages ranging from 3 to 17 years, have a particularly worrying situation with a strong negative impact on the educational process, which must be an alarm signal. Carbon dioxide present in indoor air can have negative effects on the concentration and attention of children, thus affecting the learning process. It can also cause a drowsiness or headache.

Due to their abundant nature, Volatile Organic Compounds (VOCs) are crucial parameters for assessing air quality both internally and externally environment. This class of compounds includes a wide range of air pollutants with a significant impact on atmospheric air and human health (Kumar et al., 2014, Lerner et al., 2012, Matsumoto et al., 2010) [15, 16, 17]. The chemical

\footnotetext{
* Corresponding author: tiberiu.catalina@gmail.com
} 
variety of a VOC group constitutes the cause of negative impact factor on human health, ranging from noncancerous to carcinogenic effects (Kumar et al., 2014; Lerner et al., 2012; Srivastava et al., 2005; Ramirez et al., 2012) [15, 16, 18, 19].

\section{Study case}

The study presents the results obtained from the monitoring campaign conducted at "Mihai Viteazul" High School from Bucharest, Romania and is based on the comparative analysis of two different classrooms, one equipped with a mixed hybrid air ventilation system (I-17) and the other one does not have an air ventilation system (I-16). These two classrooms are located on the first floor of the building, consisting of ground floor and two levels, put into use in 1926.
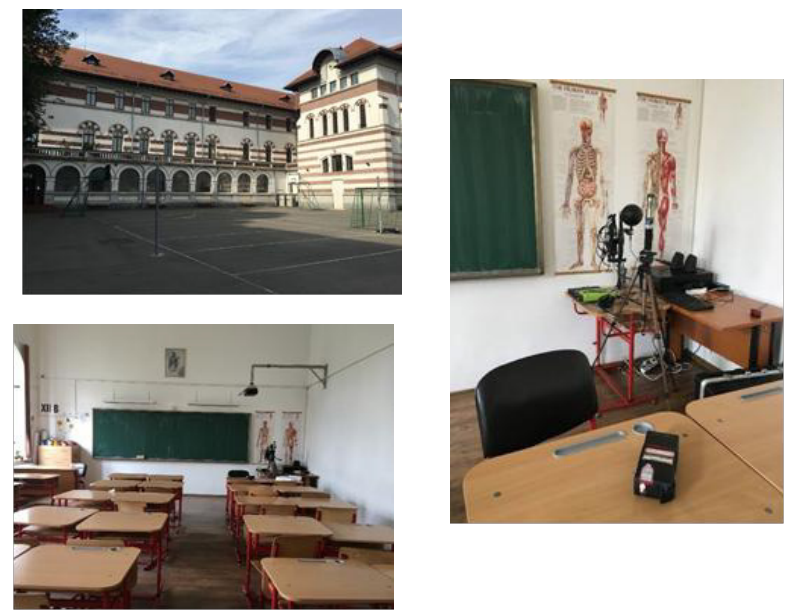

Fig. 1. Classroom with air ventilation system and detail of the equipment's location.

The two classrooms are oriented to the south and the volume of this was $299.88 \mathrm{~m}^{3}$. The interior finishes were consisted of: layered laminate parquet for flooring, water dispersion paint for wall and vinyl polychloride joinery with thermo-insulating glass for windows. The heating of spaces is normally carried out by the centralized heat supply system using steel radiators with a length of 2,000 mm. During of entire measuring period, the heating system was not active. The furniture elements are specific to classrooms and are made of MDF (medium density fibreboard) panels. Moreover, in the space equipped with the air ventilation system (I-17), are present the electronic equipment's (computer, projector) and decorative plants. The number of occupants varied in these two classrooms, reaching a maximum value of 30 persons.

For the first classroom (I-17) with ventilation systems, the main component of the ventilation system was the Xpelair GX9 fan with application for schools. The diameter of the ventilator fan is of $266 \mathrm{~mm}$ in reversible range and with enclosed external rotor motors. The system is controlled by an automatic module that allow the modification of the fresh air flow from 150 to 600 $\mathrm{m}^{3} / \mathrm{h}$. During the experimental measurements the fresh air flow was set at $450 \mathrm{~m}^{3} / \mathrm{h}$ or approx. $20 \mathrm{~m}^{3} / \mathrm{h} /$ student. The extraction of the air is realized using an extraction outlet mounted in the classroom door.

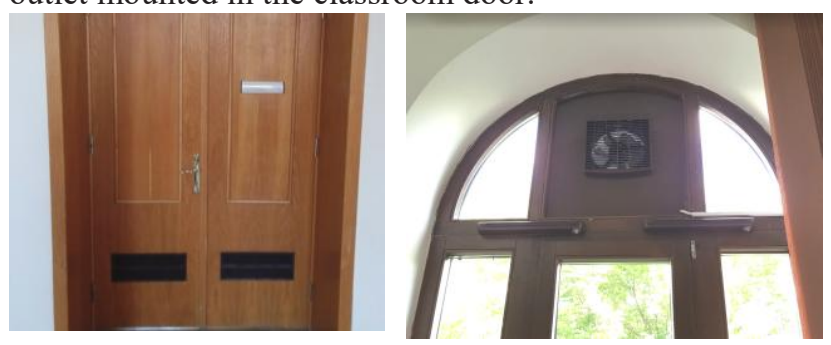

Fig. 2. Photos with the window fan + hygro-adjustable grids and the extraction outlets in the door

The proposed system is functioning only if the hygroscopic air vents mounted in the windows frame don't allow sufficient fresh flow. These air vents are Eha2 Aereco hygro-adjustable grids and six of them were installed allowing a maximum fresh air flow of $180-200 \mathrm{~m}^{3} / \mathrm{h}$ depending on the pressure difference indoor/outdoor and indoor humidity.

\subsection{Monitoring method}

The volatile organic compounds, benzene, toluene and formaldehyde have been selected based on their effects on human health. Previous studies mention that the breathing benzene can cause the onset of illness, accompanied by slight irritation of the eyes and mucous membranes. If benzene is aspirated directly into the lungs it can lead to acute haemorrhagic pneumonitis. Major concerns benzene toxicity includes anaemia and acute leukaemia. Also, benzene is a known carcinogen while toluene is toxic at high concentrations (Khoder, 2006) [20]. Sources of benzene concentrations may be paints, furniture wax, lubricants and glues (Kumar et al., 2014) [15]. Formaldehyde is the simplest and most common aldehyde found in the environment and is perhaps the most important pollutant of the indoor environment due to its frequency of occurrence and the irritating potentially it has over the occupants (Occupational Health Guideline for Formaldehyde) [21], being toxic and irritating to the respiratory tract, eyes and skin and carcinogenic to humans at high concentrations (Khoder, 2006) [20]. Indoor concentrations of formaldehyde vary and are influenced by temperature, humidity, ventilation rate, building age, presence of combustion sources, type of indoor activity, etc.

All the measurements were performed in accordance with a standardized method based on the standards EN1525 and World Health Organisation -Guidelines for Indoor Air Quality: Selected Pollutants), using a monitoring protocol, which includes the specifications regarding the location area of equipment's installation (adjacent from the ventilation system) and the setting of the chemical compounds and the monitoring interval.

The monitoring process of benzene and toluene was conducted using a real time detection method with GrayWolf DirectSense IQ-610 portable data-logging 
detector. In this case, the device is based on a photoionization detector (PID) for VOCs (Vasile et al., 2011) [22].

For detection of formaldehyde present in the indoor air, we used a gas detector whose principle of operation is based on photoelectric photometry that involves the existence of a standard pill containing the test paper treated with special chemicals, an illuminating agent and a light beam. When gas is blown onto the standard pill, the paper emits illumination by chemical reaction and this causes the paper to change colour. The amount of colour change is determined by the level of formaldehyde exposure and the time of exposure. In this campaign, the sampling time used for formaldehyde monitoring was 15 minutes. In every classroom, the level of formaldehyde concentration was equal $(<0.01 \mathrm{ppm})$ and below the permissible limit.

The volatile organic compounds have been measured continuously throughout the course hours starting with 7:41 AM, and recording the concentrations every minute.

Along with the measurements of the volatile organic compounds, have also been monitored indoor environmental parameters by measuring carbon monoxide and carbon dioxide concentrations, temperature and humidity. We chose to monitor the concentration of carbon monoxide next to carbon dioxide because an accumulation of this odourless, colourless gas in indoor air can be toxic for human body due to the affinity for combination with hemoglobin and forming carboxyhemoglobin $(\mathrm{COHb})$ which leads to disrupting oxygen transport. This parameter was considered an indicator of indoor air quality. In this case the source of carbon monoxide is only from outdoor air into the indoor environment. This parameter was considered an indicator of indoor air quality. In this case the source of carbon monoxide is only from outdoor environment.

Indoor air parameters monitoring was carry out by using several measuring principles, presented in table 1 . Before the starting of the measurements, it was performed the calibration of the equipment.

Table 1. Measuring principles for detection indoor air parameters

\begin{tabular}{lccc}
\hline Parameter & $\begin{array}{c}\text { Measuring } \\
\text { principle }\end{array}$ & Range & Accuracy \\
\hline $\begin{array}{l}\text { Carbon } \\
\text { monoxide }\end{array}$ & Electrochemical & $\begin{array}{c}0 \div 500 \\
\mathrm{ppm}\end{array}$ & $\pm 2 \mathrm{ppm}$ \\
& & & \\
$\begin{array}{l}\text { Carbon dioxide } \\
(\mathrm{CO})\end{array}$ & NDIR & $0 \div 10,000$ & $\pm 50 \mathrm{ppm}$ \\
Relative & Cappm & \\
humidity & probe & $0 \div 100 \%$ & $\pm 2 \% \div$ \\
Temperature & Thermal & $-25^{\circ} \div$ & $\pm 0.3^{\circ} \mathrm{C}$ \\
& resistance Pt 100 & $+70^{\circ} \mathrm{C}$ & \\
\hline
\end{tabular}

\section{Results and interpretation}

The contribution of this solution for air ventilation is also observed in the recorded values for the concentrations of the total volatile organic compounds, the mean values being lower compared to the nonventilated space. Also, in our previous experimental campaigns in kindergartens, TCOV concentration had the highest average value of $0.52 \mathrm{ppm}$ (minimum 0.23 ppm - maximum $0.85 \mathrm{ppm})$, in isobutylene units $1,193.349 \mu \mathrm{g} / \mathrm{m}^{3}\left(527.82-1,950.659 \mu \mathrm{g} / \mathrm{m}^{3}\right)$, while in secondary or high schools, it recorded average values of $1.11 \mathrm{ppm}\left(2,547.329 \mu \mathrm{g} / \mathrm{m}^{3}\right)$, with a minimum of 0.18 ppm $\left(413.08 \mu \mathrm{g} / \mathrm{m}^{3}\right)$ and a maximum of $1.85 \mathrm{ppm}$ $\left(4,199.649 \mu \mathrm{g} / \mathrm{m}^{3}\right)$ (Vasile et al., 2016c) [9].

The mean concentration of TVOC recorded in our previous campaign in office spaces was between 0.03 ppm and 0.3 ppm (69.1-690.8 $\mu \mathrm{g} / \mathrm{m}^{3}$ isobutylene units, at $24{ }^{\circ} \mathrm{C}$ and 1 atm (Vasile et al., 2015) [23, 24], in residential spaces, the values ranged between $0.16 \mathrm{ppm}$ and 0.36 ppm (Vasile and Dima, 2015) [23, 24], and in a chemistry lab was recorded an average of $0.25 \mathrm{ppm}$ (0.20 ppm minimum - maximum $0.35 \mathrm{ppm}$ ), isobutylene units $573.72 \mu \mathrm{g} / \mathrm{m}^{3}$ (minimum $458.97 \mu \mathrm{g} / \mathrm{m}^{3}$ - maximum $803.21 \mu \mathrm{g} / \mathrm{m}^{3}$ ) (Vasile et al., 2016a) [7]. Our results are comparable with the similar studies conducted in earlier years. Recently, Kumar et al., 2014 [15] reported the mean concentration of TVOC as $465.8 \mu \mathrm{g} / \mathrm{m}^{3}(145.3-$ $\left.1,503.2 \mu \mathrm{g} / \mathrm{m}^{3}\right)$ in winter and $321.8 \mu \mathrm{g} / \mathrm{m}^{3}(90.7-1,100.9$ $\mu \mathrm{g} / \mathrm{m}^{3}$ ) in summer for indoor air of the library of Jawaharlal Nehru University, New Delhi, a range of 100 and $538 \mu \mathrm{g} / \mathrm{m}^{3}$ for TVOC concentrations was reported in indoor air of Japanese University (Hori et al., 2012) [25]. Sarkhosh et al., 2012 [26] measured the concentrations in range from 113.4 to $486.3 \mathrm{ppm}\left(227-973 \mu \mathrm{g} / \mathrm{m}^{3}\right.$ isobutylene units) in photocopy centres and Chan et al., (2009) [27] recorded TVOC concentrations in new hotels guest rooms of the factory region which varied between 416 and $2,900 \mu \mathrm{g} / \mathrm{m}^{3}$.

Benzene concentration of $0.1 \mathrm{ppm}$ recorded in this campaign is at the minimum level registered in kindergartens (between $0.1 \mathrm{ppm}$ and $0.5 \mathrm{ppm}$ ) (National Project PN 091404 02, phase no. 22, 2015) [13] and another secondary high schools from Bucharest (between $0.1 \mathrm{ppm}$ and $0.9 \mathrm{ppm}$ ).

Our previous studies showed levels of benzene mean concentration of $0.3 \mathrm{ppm}\left(958.4 \mu \mathrm{g} / \mathrm{m}^{3}\right)$ in residential spaces and $0.2 \mathrm{ppm}\left(638.9 \mu \mathrm{g} / \mathrm{m}^{3}\right)$ in office spaces (Vasile et al., 2016b) [8], within PELs, and $0.13 \mathrm{ppm}$ $\left(415.30 \mu \mathrm{g} / \mathrm{m}^{3}\right)$, with a minimum of $0.10 \mathrm{ppm}(319.59$ $\left.\mu \mathrm{g} / \mathrm{m}^{3}\right)$ and a maximum of $0.20 \mathrm{ppm}\left(638.94 \mu \mathrm{g} / \mathrm{m}^{3}\right)$ in a chemistry lab (Vasile et al., 2016a) [7], but were higher than those reported in indoor air of Egyptian offices (4.32 ppb) (Khoder, 2006) [20], or in the library of Jawaharlal Nehru University, New Delhi (7.2-12.2 $\mu \mathrm{g} / \mathrm{m}^{3}$ ) (Kumar et al., 2014) [15], or in indoor air of offices from NCSR "Demokritos", Aghia Paraskevi, Athens (15.3-17.6 $\mu \mathrm{g} / \mathrm{m}^{3}$ ) (Saraga et al., 2011) [28].

In the classroom without air ventilation system has been recorded the presence of toluene with an average value of $0.1 \mathrm{ppm}$ and a maximum concentration of $0.2 \mathrm{ppm}$ compared to classroom with ventilation solution, where this compound was not present in indoor air. 
Since the classrooms are similarly from the dimensional point of view and from the finishing products, we can consider a constant contribution of these parameters, the comparison of the recorded values based on the influence of the space ventilation solution.

At the end of the monitoring program it was observed that all the specific volatile organic compounds are below of the permissible exposure limits. However, from a comparative point of view, it can be notice the presence of benzene and toluene in classroom without air ventilation system versus the classroom with ventilation solution. This concentration of the specific organic compound is also reflected in the concentration values of total volatile organic compounds.

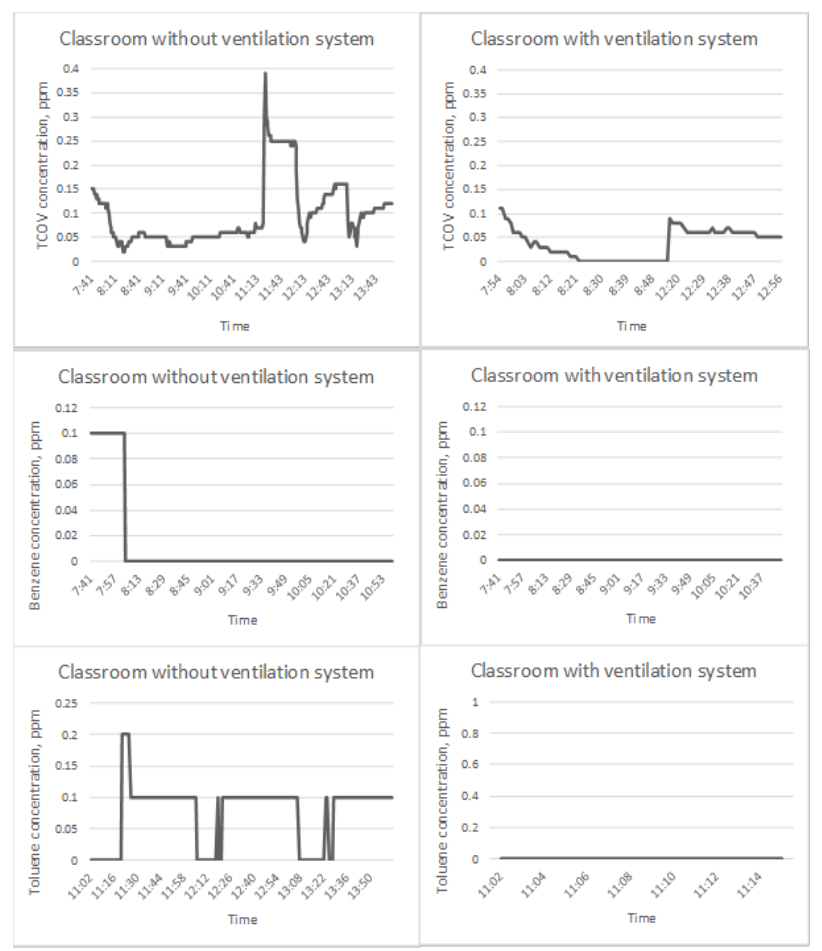

Fig. 3. Comparison between non-ventilated and ventilated classroom for TCOV, Benzene and Toluene.

Table 2. Monitored compound and environmental conditions.

\begin{tabular}{|c|c|c|c|c|c|c|c|c|}
\hline \multirow{2}{*}{  } & \multicolumn{8}{|c|}{$\begin{array}{l}\text { Monitored compound and anvirommental condititions } \\
\text { Average value (min max) } \\
\end{array}$} \\
\hline & $\begin{array}{c}\text { Tcov, } \\
\text { ppm }\end{array}$ & $\begin{array}{c}\text { Benzane, } \\
\text { ppm }\end{array}$ & Toluena, prm & $\begin{array}{c}\text { Formaldehyde, } \\
\text { ppm } \\
(15 \mathrm{~min})\end{array}$ & $\mathrm{CO}_{2, \mathrm{ppm}}$ & $C 0, p p m$ & $\mathrm{~T},{ }^{\circ} \mathrm{C}$ & RH, \% \\
\hline & & & & room rith rean & lation system (I) & & & \\
\hline AMI:44-08:53 & $\begin{array}{l}0.02 \\
(0.0 .11)\end{array}$ & 0 & unmessured & 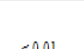 & $\begin{array}{l}1,1,21 \\
(8802,379)\end{array}$ & $\begin{array}{l}1.1 \\
(0.91 .4)\end{array}$ & $(22.825 .8)$ & $\begin{array}{l}35.2 \\
(33.637 .0)\end{array}$ \\
\hline $\begin{array}{l}12: 17-12: 56 \\
\text { AMI }\end{array}$ & $\begin{array}{l}0.06 \\
(0.050 .09)\end{array}$ & unmessurad & 0 & 0.01 & $\begin{array}{c}1,897 \\
(1,7102,026)\end{array}$ & $(0.50 .8)$ & $\begin{array}{ll}25.1 \\
(23.925 .8)\end{array}$ & $\begin{array}{l}35.1 \\
(33.338 .9)\end{array}$ \\
\hline $\begin{array}{l}\text { 07:41AM- } \\
\text { 08:03 AMI }\end{array}$ & $(0.100 .15)$ & $0.1^{*}$ & $\begin{array}{l}\text { Clas } \\
\text { unmessured }\end{array}$ & om rithout tre & $\begin{array}{c}\text { tilation sistem } \\
1,317 \\
(1,1391,564)\end{array}$ & $\begin{array}{c}-16) \\
1.1 .1 \\
(1.01 .2)\end{array}$ & $(24.32 .36 .0)$ & $\begin{array}{r}355.77 .0) \\
(34.937 .0)\end{array}$ \\
\hline $\begin{array}{l}08: 04 . \mathrm{AM}- \\
\text { 10:59:MM }\end{array}$ & $(0.020 .08)$ & 0 & unmasurued & $<0.01$ & $\begin{array}{l}1,872 \\
(1,0002,567)\end{array}$ & $(0.41 .11)$ & $\begin{array}{l}27.0 \\
(24.528 .0)\end{array}$ & $\begin{array}{l}34.0 \\
(30.835 .9)\end{array}$ \\
\hline $\begin{array}{l}\text { 11:02 AM- } \\
\text { 14:03 AMM }\end{array}$ & $\begin{array}{l}0.14 \\
(0.030399)\end{array}$ & unmeasurad & $\begin{array}{l}0.1 \\
(00.2)\end{array}$ & & $\begin{array}{c}2,691 \\
(1,30303,492)\end{array}$ & $\begin{array}{l}0.5 \\
(0.10 .8)\end{array}$ & $\begin{array}{l}27.2 \\
(25.528 .2)\end{array}$ & $\begin{array}{c}37.9 \\
(30.742 .4)\end{array}$ \\
\hline $\begin{array}{l}\text { Permisible } \\
\text { erpposure limits } \\
\text { (PELs), ppm }\end{array}$ & . & 1 & 200 & $\begin{array}{c}\text { Class E } \\
(\leq 0.041) \\
(\leq 2)\end{array}$ & 800 & 9 & & \\
\hline
\end{tabular}

\section{Conclusions}

Within this article we have realized experimental campaign with the purpose to compare indoor air pollutants in case of two ventilation strategies. Two identical classrooms as shape, volume, about the same number of students, orientation and furniture was compared. The difference in comparing indoor air pollutants was the using of hybrid ventilation (natural ventilation with humidity sensitive air vents added with window fan) for one classroom and only natural ventilation for other classroom. In this way, it has been demonstrated that can be obtained good air quality using hybrid ventilation. After the analysis of the measured data using professional equipment with GrayWolf Direct Sense IQ-610 portable data-logging detector we can conclude that it is necessary the introduction even more of fresh air to reduce $\mathrm{CO}_{2}$ limit at $800 \mathrm{ppm}$ in both classroom, more acceptable values obtaining using hybrid ventilation. The same for VOC, CO and for other pollutants have been obtained good permissible exposure values using hybrid ventilation. In these conditions, using hybrid ventilation to achieve more suitable limits for indoor air pollutants concentration can allow more fresh airflow rates.

\section{Acknowledgements}

The research article is supported by the project ID P_37_229, SMIS 103427, Contract No. 22/01.09.2016, with the title „Smart Systems for Public Safety through Control and Mitigation of Residential Radon linked with Energy Efficiency Optimization of Buildings in Romanian Major Urban Agglomerations SMART-RADEN" supported by the Competitiveness Operational Program 2014-2020, POC-A.1- A.1.1.4 -E- 2015 competition.

\section{References}

[1]. C. Soviany, Embedding Data and Task Parallelism in Image Processing Applications, $\mathrm{PhD}$ Thesis, Technische Universiteit Delft, 2003

[2]. T. Ugranli, M. Toprak, G. Gursoy, A.H. Cimrin, S.C. Sofuoglu, Indoor environmental quality in chemistry and chemical engineering laboratories at Izmir Institute of Technology, Atmospheric Pollution Research 6, 147-153, 2015

[3]. L. Zhong, F.C. Su, S. Batterman, Volatile organic compounds (VOCs) in conventional and high performance school buildings in the U.S., Int.J.Environ.Res.Public Health 14, 100-118, 2017

[4]. S.S.H. Ho, Y. Huang, S.C. Lee, J. Cao, Challenges on field monitoring of indoor air quality in China, Indoor and Built Environment, available on https://www.researchgate.net/publication, 2016

[5]. V. Vasile, H. Petran, A. Dima, C. Petcu, Indoor air quality - a key element of the energy performance of the buildings, Jarek Kurnitski, Energy Procedia Sustainable Built Environment Tallinn and Helsinki Conference SBE16 Build Green and Renovate Deep, 972 pag., ISSN 1876-6102, pag. 277-284, available at www.sciencedirect.com, 2016 
[6]. V. Vasile, A. Dima, M. Ion, Indoor air quality in built environment subject to vibrations generated by non-seismic sources, Conferinţa de cercetare în construcţii, economia construcţiilor, urbanism şi amenajarea teritoriului. Rezumate ale lucrărilor, ISSN 2343-7537, indexată în Ulrich's, ProQuest şi Europa World of Learning/Routledge, disponibil la http://pub.incd.ro/, 2016

[7]. V. Vasile, A. Dima, M. Ion, Indoor air quality in built environment subject to vibrations generated by non-seismic sources, Conferinţa de cercetare în construcţii, economia construcţiilor, urbanism şi amenajarea teritoriului. Rezumate ale lucrărilor, ISSN 2343-7537, indexată în Ulrich's, ProQuest şi Europa World of Learning/Routledge, disponibil la http://pub.incd.ro/, 2016a

[8]. V. Vasile, A. Dima, M. Ion, Monitoring of indoor air pollution in residential and office spaces, 16th International Multidisciplinary Scientific GeoConference SGEM 2016,www.sgem.org, SGEM2016 Conference Proceedings, ISBN 978-6197105-64-3 / ISSN 1314-2704, June 28 - July 6, 2016, Book4 Vol. 2, 467-474 pp, 2016b

[9]. V. Vasile, A. Dima, M. Ion, Children exposure to volatile organic compounds in indoor air of Bucharest educational spaces, Proceedings of The 8th Edition of European Exhibition of Creativity and Innovation - EUROINVENT 2016, Romanian Inventors Forum, Iaşi, 492 pag., pag. 429-430, disponibil http://www.euroinvent.org/cat/e2016.pdf, 2016c

[10]. Ocuppational Safety \& Health Administration (OSHA) Standards - Permissible Exposure Limits (PELs)

[11]. The project PN 091404 02, Concepts of making green buildings, in embodiments and of environmentally friendly materials, with low energy, phase no.7, May 2012

[12]. V. Vasile, A. Dima, M. Ion, Monitoring of the inorganic pollutants in built indoor environment, Rev.Chem.(Bucharest), 68 (1):85-89, available at http://www.revistadechimie.ro/, 2017

[13]. The project PN 091404 02, Concepts of making green buildings, in embodiments and of environmentally friendly materials, with low energy, phase no.22, November 2015

[14]. The project PN 091404 02, Concepts of making green buildings, in embodiments and of environmentally friendly materials, with low energy, phase no.23, December 2015

[15]. A. Kumar, B.P. Singh, M. Punia, D. Singh, K. Kumar, V.K. Jain, Assessment of indoor air concentrations of VOCs and their associated health risks in the library of Jawaharlal Nehru University, New Dehli, Environ Sci Pollut Res, 21:2240-2248, 2014

[16]. J.E. Lerner, E.Y. Sanchez, J.E. Sambeth, A.A. Porta, Characterization and health risk assessment of VOCs in occupational environments in Buenos Aires, Argentina, Atmos Environ, 55:440-447, 2012
[17]. K. Matsumoto, R. Mizuno, M. Igawa, Volatile organic compounds in ambient aerosols, Atmos Res, 97:124-128, 2010

[18]. A. Srivastava, B. Sengupta, S.A. Dutta, Source Apportionment of ambient VOCs in Delhi City, Sci Total Environ 343(1-3):207-220, 2005

[19]. N. Ramirez, A. Cuadras, E. Rovira, F. Borrull, R.M. Marce, Chronic risk assessment of exposure to volatile organic compounds in the atmosphere near the largest Mediterranean industrial site, Environ Int, 39:200-209, 2012

[20]. M.I. Khoder, Formaldehyde and Aromatic Volatile Hydrocarbons in the Indoor Air of Egyptian Office Buildings, Indoor and Built Environment, 15, pp 379-387, 2006

[21]. Ocupational Health Guideline for Formaldehyde National Institute for Occupational Safty and Health, US Department of Health and Human Services

[22]. V. Vasile, A. Cioacă (Dima), Metode şi tehnici experimentale pentru determinarea emisiilor provenite din materialele de construcţii, Urbanism, Arhitectură, Construcţii, 2(2):63-66, 2011

[23]. V. Vasile, A. Dima, C. Stamate, Indoor air pollution and their associated health risks, Conference Importance of Place - Conference Proceedings, Sarajevo, 21-23 oct.2015, CICOPBH, Sarajevo, vol.3, no.1, pp.277-291, 2015

[24]. V. Vasile, A. Dima, Indoor environment - air quality and the risks on human health, Studia UBB Ambientum, LX, 1-2, pp.137-145, 2015

[25]. H. Hori, S. Ishimatsu, Y. Fueta, T. Ishidao, Evaluation of a real-time method for monitoring volatile organic compounds in indoor air in a Japanese university, Environ Health Prev Med. doi:10.1007/s12199-012-0319-1, 2012

[26]. M. Sarkhosh, A.H. Mahvi, M.R. Zare, Y. Fakhri, H.R. Shamsolahi, Indoor contaminants from hardcopy devices: characteristics of VOCs in photocopy centers, Atmos Environ 63:307-312, 2012

[27]. W. Chan, S. Lee, Y. Chen, B. Mak, K. Wong, C. Chan, Indoor air quality in new hotels' guest rooms of themajor world factory region, Int J Hosp Manag 28:26-32, 2009

[28]. D. Saraga, S. Pateraki, A. Papadopoulos, C. Vasilakos, T. Maggos, Studying the indoor air quality in three non-residential environments of different use: a museum, a printery industry and an office, Building and Environment 46, pp 2333-2341, 2011 